\title{
Peran Penyuluh Pertanian Lapangan Terhadap Kinerja Kelompok Tani Di Kecamatan Sumbergempol Kabupaten Tulungagung
}

\section{Tri Wahyuning Tyas}

\author{
Program Studi Magister Agribisnis Program Pascasarjana \\ Universitas Islam Kadiri \\ Jl. Sersan Suharmaji No. 38 Kota Kediri Jawa Timur Telp./Fax. (0354) 683243
}

\begin{abstract}
Abstrak
Peran Penyuluh Pertanian Lapangan adalah membantu petani membentuk pendapat yang sehat dan membuat keputusan yang baik dengan cara berkomunikasi dan memberikan informasi yang sesuai dengan kebutuhan petani. Penyuluh Pertanian Lapangan merupakan agen bagi perubahan perilaku petani dan penyuluh pertanian lapangan membantu petani untuk meningkatkan usaha tani sehingga kinerja petani akan meningkat. Melalui pengorganisasian petani dalam kelompok - kelompok maka diharap dapat terjalin kerjasama antar individu, antar kelompok dimana kelompok berfungsi sebagai kelas belajar, wadah belajar dan unit produksi. Kelompoktani merupakan wadah belajar mengajar bagi anggotanya guna meningkatkan pengetahuan, ketrampilan sikap dan perilaku petani serta tumbuh dan berkembangnya kemandiriannya dalam berusahatani sehingga produktivitasnya meningkat, pendapatanya bertambah serta kehidupan yang sejahtera. Tujuan penelitian ini adalah untuk mengidentifikasi peran penyuluh pertanian lapangan terhadap kinerja kelompok tani. Jenis penelitian crossectional dengan sampel petani di Kecamatan Sumbergempol Kabupaten Tulungagung. Pengumpulan data dilakukan dengan menggunakan kuisioner. Data dianalisis secara kuantitatif dengan menggunakan uji statistik spearman rank korelasi.
\end{abstract}

Keywords: Penyuluh Pertanian Lapangan, Kinerja Kelompok Tani.

\section{PENDAHULUAN}

Sektor pertanian mempunyai peranan strategis sebagai penyediaan pangan rakyat Indonesia, berkontribusi nyata dalam penyediaan bahan baku industri, bioenergi, penyerapan tenaga kerja yang berdampak pada penurunan tingkat kemiskinan dan menjaga pelestarian lingkungan. Dengan kata lain, pertumbuhan pertanian yang berhasil dapat diartikan jika terjadi pertumbuhan yang tinggi sekaligus terjadi perubahan masyarakat tani dari yang kurang baik menjadi yang lebih baik. Seperti diketahui sektor pertanian di Indonesia dianggap penting. Oleh karena itu wajar jika biaya pembangunan untuk sektor pertanian ini selalu tiga besar diantara sektor-sektor yang lain. Sejalan dengan hal tersebut, Kementerian Pertanian Tahun 2010 2014 telah menetapkan visi, yaitu "Pertanian Industrial Unggul Berkelanjutan, Berbasis Sumberdaya Lokal untuk Meningkatkan Kemandirian Pangan, Nilai Tambah, Ekspor dan $\begin{array}{lcr}\text { Kesejahteraan } & \text { Petani" } & \text { (Peraturan } \\ \text { Menteri } & \text { Pertanian } & \text { No } \\ \text { 82/Permentan/OT.140/8/2013). } & \end{array}$

Untuk mewujudkan visi tersebut diperlukan pelaku utama dan pelaku usaha yang berkualitas, andal, berkemampuan manajerial, kewirausahaan dan organisasi bisnis. Dengan demikian, mereka diharapkan mampu membangun usahatani berdaya saing dan berkelanjutan sehingga dapat meningkatkan posisi tawarnya. Oleh karena itu, kapasitas dan kemampuan mereka harus terus ditingkatkan, salah satunya melalui penyuluhan dengan pendekatan kelompok (Permentan RI No. 82, 2013).

Permasalahan utama penyuluh pertanian di Indonesia bukan hanya jumlahnya yang kurang akan tetapi sekarang kualitasnyapun perlu ditingkatkan. Rendahnya kualitas penyuluh pertanian sebagai akibat dari kurangnya pelatihan dan rendahnya mutu pendidikan para penyuluh. Hal tersebut berdampak pada proses pembelajaran 
bagi para petani, penyuluh kurang mendapat respon dari petani dan bahkan penyuluh sering minder berhadapan dengan petani yang lebih menguasai permasalahan dilapangan (Sinar Tani, 2014).

Penyuluhan pertanian yang sebelumnya hanya berfokus pada kegiatan transfer teknologi bagi petani dan keluarganya kini memiliki cakupan lebih luas, yaitu mencakup keseluruhan proses pembelajaran bagi pelaku utama dan pelaku usaha agar mereka mau dan mampu menolong dan mengorganisasikan dirinya dalam mengakses informasi pasar, teknologi, permodalan dan sumberdaya lainnya sebagai upaya meningkatkan produktivitas, efisiensi usaha, pendapatan dan kesejahteraannya serta meningkatkan kesadaran dalam pelestarian fungsi lingkungan hidup (BPSDM Deptan, 2009).

Belum optimalnya peranan penyuluhan pertanian dapat disebabkan oleh rendahnya tingkat partisipasi petani terhadap penyuluh pertanian sebagai akibat rendahnya mutu pelayanan penyuluhan pertanian. Selain itu lemah dan tidak sistematisnya sistem pendanaan sehingga menjadi salah satu penyebab rendahnya kinerja penyuluh pertanian dalam menjalankan tugas dan fungsinya. Penyuluh pertanian kedepan adalah penyuluh pertanian yang dapat menciptakan dirinya sebagai mitra dan fasilitator petani dengan melakukan peranan yang sesuai antara lain sebagai : penyedia jasa pendidikan (educator), motivator, konsultan (pembimbing), dan pendamping petani (Rasyid, 2001).

Hermayunita (2011), Peran penyuluh pertanian lapangan (PPL) dalam penerapan pertanian organik menunjukkan bahwa penyuluh sudah berperan dengan baik sesuai dengan tugas dan fungsinya yaitu dengan mengunjungi petani, memberikan pelatihan kepada petani, membantu petani membuat pestisida nabati, membantu petani dalam pemecahan masalah usaha tani dan membuat laporan pelaksanaan kegiatan.

Peranan agen penyuluh pertanian adalah membantu petani membentuk pendapat yang sehat dan membuat keputusan yang baik dengan cara berkomunikasi dan memberikan informasi yang sesuai dengan kebutuhan petani. Peranan utama penyuluhan lebih dipandang sebagai proses membantu petani untuk mengambil keputusan sendiri dengan cara menambah pilihan bagi mereka, dan menolong petani mengembangkan wawasan mengenai konsekuensi dari masing-masing pilihan tersebut (Kartasapoetra, 1994).

Menurut Hawkins (1999), agen penyuluhan dapat membantu petani memahami besarnya pengaruh struktur sosial ekonomi dan teknologi untuk mencapai kehidupan yang lebih baik, dan menemukan cara mengubah struktur atau situasi yang menghalanginya untuk mencapai tujuan tersebut. Mereka dapat membantu petani meramalkan peluang keberhasilan dengan segala konsekuensinya, dengan memberikan wawasan luas yang dapat dipengaruhi oleh berbagai aspek sosial dan ekonomi.

Tugas pokok penyuluh pertanian secara garis besar adalah melakukan kegiatan dari mulai persiapan, pelaksanaan dan evaluasi. Dengan fungsi komunikasi yaitu menyampaikan/menyebarluaskan informasi, memperluas wawasan, menciptakan iklim yang kondusif bagi perubahan, meningkatkan aspirasi, mengajarkan kompetensi, meningkatkan motivasi dan inisiatif petani. Kegiatan persiapan penyuluhan pertanian diawai dengan mengidentifikasi potensi dan permasalahan yang ada yang kemudian dijadikan rumusan akan apa yang dapat dilakukan untuk mengatasi masalah tersebut dengan memanfaatkan potensi yang ada, atau penyuluh biasa melakukan pada kegiatan programa penyuluhan pertanian. Tujuan penyuluhan pertanian adalah berubahnya perilaku petani yang mencakup perubahan dalam hal pengetahuan atau hal yang diketahui, perubahan dalam keterampilan atau kebiasaan dalam melakukan sesuatu dan perubahan dalam sikap dan mental kearah yang lebih baik dengan tujuan akhir penyuluhan adalah kesejahteraan hidup yang lebih baik.

Usaha - usaha untuk merubah perilaku masyarakat atau kelompoktani melalui 
perubahan sosial yang direncanakan (planet social change). Merupakan salah satu tujuan program penyuluhan pertanian lapangan, dalam hal ini diarahkan untuk memperbaiki sistem - sistem sosial yang terdapat pada masyarakat secara keseluruhan. Sistem sosial ini dapat berupa keluarga, rukun tetangga, rukun warga, kelompok dasa wisma, kelompok tani, koperasi unit desa dan lain - lain. Setiap sistem sosial ini anggota anggotanya bekerja sama untuk memecahakan masalah secara bersama. Tujuan bersama ini dapat berupa upaya meningkatkan pengetahuan dan ketrampilan terhadap teknik budidaya tertentu, meningkatkan ketersediaan input produksi setempat dan meningkatkan produksi pendapatan petani.

Melalui pengorganisasian petani dalam kelompok - kelompok maka diharap dapat terjalin kerjasama antar individu, antar kelompok dimana kelompok berfungsi sebagai kelas belajar, wadah belajar dan unit produksi. Kelompoktani merupakan wadah belajar mengajar bagi anggotanya guna meningkatkan pengetahuan, ketrampilan sikap dan perilaku petani serta tumbuh dan berkembangnya kemandiriannya dalam berusahatani sehingga produktivitasnya meningkat, pendapatanya bertambah serta kehidupan yang sejahtera. Menjadikan kelompoktani sebagai kelas belajar merupakan tugas penyuluh pertanian melalui bimbingan secara berkelanjutan. Oleh karena itu, diperlukan materi penyuluh pertanian yang berkaitan dengan penguatan kelompoktani sebagai kelas belajar dan wahana kerjasama. Sehingga memiliki kemapuan menyusun rencana belajar mengajar, melaksanakan dan mengevaluasi kegiatan belajar guna mengembangkan usaha untuk dapat mencapai skala ekonomi, baik dipandang dari segi kuantitas, kualitas maupun kontinuitas (Deptan, 2006).

Terdapat berbagai faktor yang mempengaruhi kemampuan penyuluh, baik secara internal maupun eksternal. Faktor internal tersebut meliputi : tingkat pendidikan, motivasi, kepribadian dan harga diri serta keadaan sosial budaya penyuluh. Adapun faktor eksternal tersebut meliputi : manajemen organisasi penyuluhan, insentif atau fasilitas yang diperoleh penyuluh dalam menjalankan tugasnya serta tingkat partisipasi sasaran yang berada dibawah koordinasinya. Faktor-faktor tersebut harus diperhatikan oleh pihak pimpinan organisasi sehingga dapat dijadikan sebagai acuan untuk mengupayakan peningkatan kompetensi penyuluh (Deptan, 2013)

\section{METODE PENELITIAN}

Penelitian ini adalah penelitian non eksperimental yaitu penelitian yang observasinya dilakukan terhadap sejumlah variabel subyek menurut keadaan apa adanya (in nature), tanpa ada manipulasi/intervensi peneliti. Metode yang digunakan adalah metode survey epidemiologic analitik yaitu menggali bagaimana dan mengapa fenomena itu terjadi yaitu dengan melakukan analisis dinamika korelasi antar fenomena. Sedangkan model/rancangan penelitian ini adalah crossectional, yaitu melihat suatu kejadian pada waktu/saat tertentu (point time approach) (Watik, 2007).

Populasi dalam penelitian ini adalah semua Penyuluh Pertanian Lapangan (PPL) yang bertugas di Kecamatan Sumbergempol dan seluruh kelompoktani yang ada di Kecamatan Sumbergempol yang hadir dalam mini lokakarya di 3 (tiga) balai desa yaitu Balai Desa Sumberdadi, Balai Desa Mirigambar dan Balai desa Trenceng.

Sampel adalah sebagian dari jumlah dan karakteristik yang dimiliki oleh populasi tersebut (Sugiyono, 2007). Sampel dalam penelitian ini adalah sebagian dari pengurus kelompoktani di Kecamatan Sumbergempol Kabupaten Tulungagung.

Sampling adalah menyeleksi porsi dari populasi untuk dapat mewakili populasi. Tehnik sampling merupakan cara-cara yang ditempuh dalam pengambilan sampel, agar memperoleh sampel yang benar-benar sesuai dengan keseluruhan obyek penelitian (Nursalam, 2001:97). Tekhnik sampling dalam penelitian ini adalah Non Probability Sampling dengan jenis Purposive Sampling yaitu suatu teknik penetapan sampel dengan cara memilih sampel diantara populasi sesuai yang dikehendaki peneliti (tujuan/masalah 
dalam penelitian), sehingga sampel tersebut dapat mewakili karateristik populasi yang telah dikenal sebelumnya (Nursalam, 2003).

Responden ditentukan dengan cara menetapkan anggota kelompok tani yang hadir dalam kegiatan mini lokakarya yang didampingi oleh petugas penyuluh pertaniannya, dan dihitung secara proporsional (Syofian, 2013). ), Selanjutnya jumlah sampel ditentukan berdasarkan rumus Solvin (Syofian, 2013). Berdasarkan perhitungan jumlah responden dengan menggunakan rumus, didapatkan hasil jumlah responden sebanyak 43 responden.

Selanjutnya untuk menentukan besar sampel masing-masing Kelompoktani digunakan teknik Probability Sampling dengan jenis Stratified Random Sampling, yaitu pengambilan sampel berdasarkan pengukuran prosentase anggota Tabel 1. Definisi Operasional Variabel

\begin{tabular}{|c|c|c|c|}
\hline \multirow{7}{*}{$\frac{\text { No }}{1}$} & Variabel & Indikator & Item \\
\hline & \multirow{6}{*}{$\begin{array}{l}\text { Peran } \\
\text { Penyuluh } \\
\text { Pertanian } \\
\text { Lapangan } \\
\text { (PPL) }\end{array}$} & & \multirow{6}{*}{$\begin{array}{l}\text { - Memberi pengetahuan petani } \\
\text { - Memberi contoh/cara baru budidaya } \\
\text { tanaman } \\
\text { - Membimbing petani } \\
\text { - Memotivasi petani } \\
\text { - Memberi petunjuk/arahan } \\
\text { - Membantu petani dengan peragaan/contoh } \\
\text { kerja }\end{array}$} \\
\hline & & Peran Pendidik & \\
\hline & & & \\
\hline & & Peran Pemımpın & \\
\hline & & & \\
\hline & & Peran Penasehat & \\
\hline \multirow[t]{4}{*}{2} & \multirow[t]{4}{*}{$\begin{array}{l}\text { Kinerja } \\
\text { Kelompok Tani }\end{array}$} & $\begin{array}{l}\text { Tingkat } \\
\text { perkembangan usaha } \\
\text { kelompoktani }\end{array}$ & $\begin{array}{l}\text { - Jumlah kelompok yang mempunyai usaha } \\
\text { (simpan pinjam, kios tani, jasa pemakaian } \\
\text { alsintan, handtraktor dan alat penggilingan } \\
\text { pupuk) }\end{array}$ \\
\hline & & $\begin{array}{l}\text { Tingkat kohesi } \\
\text { kelompoktani }\end{array}$ & - Keaktifan anggota \\
\hline & & $\begin{array}{l}\text { Sarana dan prasarana } \\
\text { kelompoktani }\end{array}$ & $\begin{array}{l}\text { - Hansprayer } \\
\text { - Perontok/penggiling padi } \\
\text { - Handtraktor } \\
\text { - Pengetahuan tentang hama wereng }\end{array}$ \\
\hline & & $\begin{array}{l}\text { Pengetahuan } \\
\text { kelompok Tani }\end{array}$ & $\begin{array}{l}\text { - Pengetahuan tentang KKKPE } \\
\text { - Pengetahuan tentang TO SORT (Tempat } \\
\text { Olahan Sampah Organik Rumah Tangga) }\end{array}$ \\
\hline
\end{tabular}

Setelah data yang diperlukan terkumpul melalui angket dan observasi maka langkah selanjutnya adalah analisa data dengan cara melakukan tabulasi/pengelompokan data yang diteliti dengan pemberian skor dan penilaian. Kemudian dilakukan analisa data dengan rumus (Arikunto, 2006). kelompoktani di WKPP I, II, III dan IV Kecamatan Sumbergempol dan menentukan sampel berdasarkan proporsi prosentase tersebut per WKPP Sumbergempol (Watik, 2007).

Sumber data yang diperoleh dan digunakan dalam penelitian ini bersumber langsung dari responden, sedangkan data sekunder bersumber dari Program Penyuluh Pertanian, IPW, Laporan Tribulan Penyuluh, Dokumentasi kegiatan penyuluhan. Pengumpulan data dilakukan dengan studi dokumentasi, kuisioner, observasi dan wawancara.

Variabel terikat dalam penelitian ini adalah Kinerja kelompok tani (Nursalam, 2003), dan Variabel bebas dalam penelitian ini adalah Peran Penyuluh Pertanian Lapangan (PPL). Definisi operasional variabel disajikan pada tabel berikut : Rumah Tangga)

$$
\begin{aligned}
& \mathrm{N}=\frac{S p}{S m} \times 100 \% \\
& \text { Keterangan: } \\
& \mathrm{N}=\text { Nilai yang didapat } \\
& S p=\text { Skor yang didapat } \\
& S m=\text { Skor maksimal }
\end{aligned}
$$

Untuk mengetahui hubungan antar variabel digunakan uji statistik Spearman 
Rank correlations dengan nilai kemaknaan $\alpha=0,05$. Apabila hasil uji statistik didapatkan $p$ value $\leq \alpha 0,05$, maka $\mathrm{Ha}$ diterima yang berarti Ada hubungan peran penyuluh pertanian lapangan dengan kinerja kelompoktani di Kecamatan Sumbergempol, Kabupaten Tulungagung. Sebaliknya apabila hasil uji statistik $p$ value > a 0,05, maka $\mathrm{Ha}$ ditolak yang berarti tidak ada hubungan peran penyuluh pertanian lapangan dengan kinerja kelompoktani di Kecamatan Sumbergempol, Kabupaten Tulungagung. Interpretasi nilai koefisien korelasi dan kekuatan hubungan sebagai berikut :

1. $0,800-0,100$ : Sangat kuat

2. $0,600-0,799$ : Kuat

3. $0,400-0,599$ : Cukup

4. 0,200-0,399: Lemah

5. $0,000-0,199$ : Sangat lemah, Syofian, 2013 ).

\section{HASIL DAN PEMBAHASAN}

\section{Kinerja Penyuluh Pertanian Kecamatan Sumbergempol}

Di

Kinerja penyuluh merupakan gambaran mengenai hasil yang dicapai oleh penyuluh dalam seluruh kegiatan penyuluhan bidang pertanian. Indikator kinerja penyuluh dijelaskan dalam petunjuk teknis supervisi, monitoring, evaluasi dan pelaporan revitalisasi penyuluh pertanian yang meliputi sembilan indikator yaitu (1) tersusunnya progam penyuluhan pertanian, (2) tersusunnya Rencana Kerja Tahunan (RKT) penyuluh pertanian, tersusunnya data peta wilayah untuk pengembangan teknologi spesifik lokasi, (3) terdiseminasinya informasi teknologi pertanian secara merata, (4) tumbuh kembangnya keberdayaan dan kemandirian pelaku utama dan pelaku usaha, (5) terwujudnya kemitraan usaha antara pelaku utama dengan pelaku usaha yang saling menguntungkan, (6) terwujudnya akses pelaku utama dan pelaku usaha ke lembaga keuangan, (7) informasi sarana produksi dan pemasaran, (8) meningkatkan produktivitas agribisnis komoditas unggulan di masing- masing wilayah kerja dan (9) meningkatnya pendapatan dan kesejahteraan pelaku utama.
Hasil penelitian mengenai kinerja penyuluh menurut persepsi kelompok tani di Kecamatan Sumbergempol sebagai berikut:

a. Tersusunnya progam penyuluhan pertanian

Penyelenggaraan program penyuluhan didasari atas upaya peningkatan kesejahteraan bagi para petani dengan semakin bertambahnya hasil pertanian. Persepsi kelompok tani atas kinerja penyuluh dalam penyusunan program penyuluhan pertanian di Kecamatan Sumbergempol sebagai berikut:

\section{Tabel 2}

Tersusunnya Program Penyuluhan Pertanian

\begin{tabular}{cccc}
\hline No & Keterangan & Frekuensi & Presentase \\
\hline 1 & Sangat Baik & 20 & 46,51 \\
2 & Baik & 23 & 53,49 \\
3 & Kurang Baik & 0 & 0 \\
4 & Tidak Baik & 0 & 0 \\
Jumlah & 43 & 100 \\
\hline
\end{tabular}

Berdasarkan tabel diatas diketahui sebanyak 23 responden atau 53,49\% menyatakan baik dan selebihnya 20 responden atau 46,51\% menyatakan sangat baik. Hal ini menggambarkan bahwa penyusunan program penyuluhan di Kecamatan Sumbergempol dapat dikatakan sangat berhasil. Upaya pemerintah melalui dinas pertanian memiliki perencanaan program penyuluhan yang cukup baik. Hal ini juga dapat dilihat dari beberapa agenda pertemuan rutin yang dilakukan oleh semua kelompok tani setiap minggu. Tingginya antusiasme para anggota kelompok tani dalam pertemuan mingguan menjadi salah satu indikator keberhasilan program penyuluhan.

\section{b. Tersusunnya Rencana Kerja} Tahunan (RKT) penyuluh pertanian

Rencana kerja tahuan merupakan bagian dari renstra (rencana strategis) jangka pendek yang hendak dicapai oleh pemerintah melalui dinas pertanian. Rencana kerja disusun didasarkan atas kebutuhan para petani (bottom up) dan program kerja pemerintah dalam skala nasional. Persepsi kelompok tani terhadap rencana kerja tahuan 
penyuluh pertanian di Kecamatan Sumbergempol sebagai berikut:

Tabel 3

Tersusunnya Rencana Kerja Tahunan (RKT) penyuluh pertanian

\begin{tabular}{clcc}
\hline No & Keterangan & Frekuensi & Presentase \\
\hline 1 & Sangat Baik & 18 & 41.86 \\
2 & Baik & 25 & 58,14 \\
3 & Kurang Baik & 0 & 0 \\
4 & Tidak Baik & 0 & 0 \\
Jumlah & 43 & 100 \\
\hline
\end{tabular}

Berdasarkan tabel diatas dapat dijelaskan bahwa penyusunan rencana kerja tahuan penyuluh pertanian di Kecamatan Sumbergempol sangat berhasil. Dari 43 responden sebanyak 25 responden atau 58,14\% menyatakan baik dan selebihnya 18 responden atau $41,86 \%$ menyatakan sangat baik.

c. Tersusunnya data peta wilayah untuk pengembangan teknologi spesifik lokasi

Penyusunan data peta wilayah digunakan sebagai pengembangan teknologi khususnya bidang pertanian yang disesuaikan dengan kondisi geografis wilayah tersebut. Persepsi anggota kelompok tani terhadap kinerja penyuluh dalam penyusunan data peta wilayah untuk pengembangan teknologi spesifik lokasi sebagai berikut:

\section{Tabel 4}

Tersusunnya data peta wilayah untuk pengembangan teknologi spesifik lokasi

\begin{tabular}{clcc}
\hline No & Keterangan & Frekuensi & Presentase \\
\hline 1 & Sangat Baik & 23 & 53,49 \\
2 & Baik & 20 & 46,51 \\
3 & Kurang Baik & 0 & 0 \\
4 & Tidak Baik & 0 & 0 \\
Jumlah & 43 & 100 \\
\hline
\end{tabular}

Berdasarkan tabel diatas dapat disimpulkan bahwa kinerja penyuluh dalam penyusunan data peta wilayah untuk pengembangan tenologi spesifik lokasi cukup berhasil. Dari 43 responden sebanyak 20 responden atau $46,51 \%$ menyatakan baik dan selebihnya 23 responden atau 53,49\% menyatakan sangat baik.

d. Terdiseminasinya informasi teknologi pertanian secara merata
Penyebaran (diseminasi) informasi teknologi pertanian untuk saat ini sudah menjadi kebutuhan dasar bagi para petani. Perkembangan ilmu pengetahuan dan teknologi tentu saja juga berimbas pada perkembangan bidang pertanian. Persepsi kelompok tani terhadap kinerja penyuluh dalam diseminasi informasi teknologi pertanian sebagai berikut:

Tabel 5

Terdiseminasinya informasi teknologi pertanian secara merata

\begin{tabular}{clcc}
\hline No & Keterangan & Frekuensi & Presentase \\
\hline 1 & Sangat Baik & 19 & 44,19 \\
2 & Baik & 24 & 55,81 \\
3 & Kurang Baik & 0 & 0 \\
4 & Tidak Baik & 0 & 0 \\
Jumlah & 43 & 100 \\
\hline
\end{tabular}

Berdasarkan hasil penelitian dalam diketahui sebanyak 24 responden atau $55,81 \%$ menyatakan baik dan selebihnya 19 responden atau 44,19\% menyatakan sangat baik. Hasil tersebut menggambarkan bahwa kinerja penyuluh dalam menyebarkan informasi teknologi di Kecamatan Sumbergempol cukup berhasil. Upaya ini memang dianggap cukup krusial, mengingat peningkatan hasil pertanian dewasa ini juga banyak dipengaruhi oleh faktor teknologi disamping dukungan dari faktor alam. Kondisi iklim yang tidak menentu tentu saja banyak diantara petani menggunakan teknologi dalam mengoptimalkan hasil pertaniannya.

e. Tumbuh kembangnya keberdayaan dan kemandirian pelaku utama dan pelaku usaha

Pemberdayaan petani menjadi salah satu target sasaran petugas penyuluh lapangan yang menjadi indikator keberhasilan kinerja PPL. Persepsi anggota kelompok tani terhadap kinerja PPL dalam menumbuh kembangkan keberdayaan dan kemandirian pelaku utama dan pelaku usaha sebagai berikut:

Tabel 6

Tumbuh kembangnya keberdayaan dan kemandirian pelaku utama dan pelaku usaha

\begin{tabular}{cccc}
\hline No & Keterangan & Frekuensi & Presentase \\
\hline 1 & Sangat Baik & 18 & 41.86 \\
\hline
\end{tabular}




\begin{tabular}{clcc}
\hline 2 & Baik & 25 & 58,14 \\
3 & Kurang Baik & 0 & 0 \\
4 & Tidak Baik & 0 & 0 \\
Jumlah & 43 & 100 \\
\hline
\end{tabular}

Berdasarkan tabel diatas diketahui bahwa kinerja penyuluh lapangan dalam menyusun Tumbuh kembangnya keberdayaan dan kemandirian pelaku utama dan pelaku usaha cukup berhasil. Hal ini dapat dilihat dari jawaban responden yang menunjukkan sebagian besar menjawab baik (58.14\%) sedangkan selebihnya sebanyak $41,86 \%$ mejawab sangat baik.

f. Terwujudnya kemitraan usaha antara pelaku utama dengan pelaku usaha yang saling menguntungkan

Kemitraan usaha merupakan jalinan kerjasama usaha yang saling menguntungkan antara pengusaha kecil dengan pengusaha menengah/besar (perusahaan mitra) disertai dengan pembinaan dan pengembangan oleh pengusaha besar, sehingga saling memerlukan, menguntungkan dan memperkuat. Persepsi kelompok tani terhadap kinerja PPL dalam mewujudkan kemitraan usaha dapat dilihat pada tabel berikut:

Tabel 7

Terwujudnya kemitraan usaha antara pelaku utama dengan pelaku usaha yang saling menguntungkan

\begin{tabular}{cccc}
\hline No & Keterangan & Frekuensi & Presentase \\
\hline 1 & Sangat Baik & 0 & 0 \\
2 & Baik & 11 & 25,58 \\
3 & Kurang Baik & 17 & 39,54 \\
4 & Tidak Baik & 15 & 34,88 \\
Jumlah & 43 & 100 \\
\hline
\end{tabular}

Berdasarkan tabel diatas diketahui sebanyak 11 responden atau 25,58\% menyatakan baik, 17 responden atau $39,54 \%$ menyatakan kurang baik dan selebihnya 15 responden atau 34,88\% menyatakan tidak baik. Kondisi ini menunjukkan bahwa petugas penyuluh lapangan belum mampu sepenuhnya mewujudkan kemitraan yang efektif antara petani dengan pelaku usaha lain yang saling menguntungkan. Padahal terwujudnya kemitraan diharapkan mampu memecahkan kendala-kendala para petani dalam bidang pemasaran.
Dengan kemitraan maka peran pengusaha besar dapat berupa pembinaan dan pengembangan, bimbingan SDM, penyandang dana atau penjamin kredit, bimbingan teknologi, menjamin pembelian hasil produksi dan promosi hasil produksi. Sedangkan pengusaha kecil dapat menerapkan teknologi dan kesepakatan dengan pengusaha besar, kerjasama antar pengusaha kecil untuk mendukung pasokan produksi kepada pengusaha besar dan pengembangan profesionalime SDM.

g. Terwujudnya akses pelaku utama dan pelaku usaha ke lembaga keuangan, informasi sarana produksi dan pemasaran

Selama ini permodalan merupakan salah satu kendala utama yang dihadapi oleh para pelaku usaha kecil terutama bagi kaum petani. Meningkatnya harga pupuk akibat kelangkaan atau permainan pedagang besar dapat memaksa petani untuk menjual hasil panen sebelum waktunya. Untuk itu diperlukan peran penyuluh dalam memberikan akses terhadap lembaga keuangan dan informasi dalam bidang pemasaran. Kinerja penyuluh dalam hal tersebut dapat dijelaskan sebagai berikut:

\section{Tabel 8}

Terwujudnya akses pelaku utama dan pelaku usaha ke lembaga keuangan, informasi sarana produksi dan pemasaran

\begin{tabular}{clcc}
\hline No & Keterangan & Frekuensi & Presentase \\
\hline 1 & Sangat Baik & 0 & 0 \\
2 & Baik & 10 & 23,25 \\
3 & Kurang Baik & 19 & 44,19 \\
4 & Tidak Baik & 14 & 32,56 \\
Jumlah & 43 & 100 \\
\hline
\end{tabular}

Berdasarkan tabel diatas diketahui sebanyak 10 responden atau $23,25 \%$ 
menyatakan baik, 19 responden atau $44,19 \%$ menyatakan kurang baik dan selebihnya 14 responden atau 32,56\% menyatakan tidak baik. Hasil tersebut menggambarkan bahwa kinerja penyuluh lapangan belum efektif dalam mewujudkan akses ke lembaga keuangan, informasi sarana produksi dan pemasaran.

h. Meningkatkan produktivitas agribisnis komoditas unggulan di masing- masing wilayah kerja

Peningkatan produktivitas hasil pertanian adalah titik berat dari program penyuluhan. Kinerja penyuluh lapangan di Kecamatan Sumbergempol pada indikator ini dapat dijelaskan sebagai berikut:

Tabel 9

Meningkatkan produktivitas agribisnis komoditas unggulan di masing- masing wilayah kerja

\begin{tabular}{clcc}
\hline No & Keterangan & Frekuensi & Presentase \\
\hline 1 & Sangat Baik & 23 & 53,49 \\
2 & Baik & 20 & 46,51 \\
3 & Kurang Baik & 0 & 0 \\
4 & Tidak Baik & 0 & 0 \\
Jumlah & 43 & 100 \\
\hline
\end{tabular}

Berdasarkan tabel diatas dapat dijelaskan bahwa sebagaian besar responden $(46,51 \%)$ menyatakan baik dan selebihnya 53,49\% menyatakan sangat baik bahwa petugas penyuluh lapangan bekerja dengan sangat baik dalam upaya meningkatkan produktivitas agribisnis komoditas unggulan di masingmasing wilayah kerja. Pada kondisi seperti itu tentu saja penyuluh akan memberikan penekanan pengelolaan yang baik pada desa yang memiliki komoditas unggulan.

i. Meningkatnya pendapatan dan kesejahteraan pelaku utama

Upaya untuk meningkatkan pendapatan dan kesejahteraan petani tentu saja berbanding lurus dengan upaya dalam mewujudkan peningkatan produktivitas hasil pertanian. Kinerja penyuluh di Kecamatan Sumbergempol dalam upaya meningkatkan pendapatan dan kesejahteraan petani dapat dilihat pada tabel berikut:
Tabel 10

Meningkatnya pendapatan dan kesejahteraan pelaku utama

\begin{tabular}{cccc}
\hline No & Keterangan & Frekuensi & Presentase \\
\hline 1 & Sangat Baik & 22 & 51,16 \\
2 & Baik & 21 & 48,84 \\
3 & Kurang Baik & 0 & 0 \\
4 & Tidak Baik & 0 & 0 \\
Jumlah & 43 & 100 \\
\hline
\end{tabular}

Berdasarkan tabel diatas diketahui sebanyak $51,16 \%$ responden menyatakan sangat baik dan selebihnya 48,84\% menyatakan baik. Hasil tersebut menggambarkan bahwa kinerja penyuluh lapangan dalam meningkatkan pendapatan dan kesejahteraan petani sudah dilakukan dengan baik. Peningkatan produktivitas hasil petanian tentu saja diharapkan akan meningkatkan kesejahteraan dan pendapatan petani di Kecamatan Sumbergempol. Upaya ini oleh para kelompok tani dipandang sudah cukup baik, meskipun dalam mewujudkan akses ke lembaga keuangan, informasi sarana produksi, pemasaran dan menjalin kemitraan dengan pihak lain dipandang masih kurang optimal.

\section{Kinerja Kelompok Tani}

Kinerja kelompok tani di Kecamatan Sumbergempol diukur dengan menggunakan indikator tingkat perkembangan usaha kelompok tani, tingkat kohesi kelompok tani, sarana dan prasarana kelompok tani, dan pengetahuan kelompok tani.

\section{a. Tingkat Perkembangan Usaha Kelompok Tani}

Berdasarkan hasil analisis data bahwa untuk mengetahui tingkat perkembangan usaha kelompok tani di Kecamatan Sumbergempol dapat dilihat pada tabel dibawah ini :

Tabel 11

Tingkat Perkembangan Usaha Kelompok

\begin{tabular}{clcc}
\multicolumn{3}{c}{ Tani } \\
\hline No & Keterangan & Frekuensi & Presentase \\
\hline 1 & Sangat Baik & 32 & 74,42 \\
2 & Baik & 7 & 16,28 \\
3 & Kurang Baik & 4 & 9,30 \\
4 & Tidak Baik & 0 & 0 \\
Jumlah & 43 & 100 \\
\hline
\end{tabular}

Dari tabel 11 menunjukkan bahwa tingkat perkembangan usaha kelompok tani mayoritas adalah kategori sangat baik, 
yaitu 32 (74,42\%), kategori baik 7 (16,28\%) dan kurang baik $4(9,30 \%)$. Hal ini disebabkan hampir semua kelompok tani mempunyai usaha yaitu berupa simpan pinjam, kios tani tingkat Poktan dan Kios Saprodi.

Tingkat perkembangan usaha kelompok tani merupakan kemampuan kelompok tani dalam melaksanakan usaha kelompoknya.

\section{b. Tingkat Kohesi Kelompok Tani}

Berdasarkan hasil analisis data bahwa untuk mengetahui tingkat perkembangan usaha kelompok tani di Kecamatan Sumbergempol dapat dilihat pada tabel dibawah ini :

Tabel 12

Tingkat Kohesi Kelompok Tani

\begin{tabular}{cccc}
\hline No & Keterangan & Frekuensi & Presentase \\
\hline 1 & Sangat Baik & 27 & 62,79 \\
2 & Baik & 7 & 16,28 \\
3 & Kurang Baik & 9 & 20,93 \\
4 & Tidak Baik & 0 & 0 \\
Jumlah & 43 & 100 \\
\hline
\end{tabular}

Dari tabel 12 menunjukkan bahwa tingkat kohesi kelompok tani sebagian besar adalah kategori sangat baik, yaitu $27(62,79 \%)$, kategori baik $7(16,28 \%)$ dan kategori kurang baik 9 (20,93\%). Ini berarti bahwa anggota kelompok tani sudah merasa dirinya bagian dari kelompok tani yang harus bertanggungjawab atas keberlangsungan kelompok. Dengan perasaan sebagai bagian dari kelompok tani maka petani akan senantiasa berusaha untuk aktif dalam setiap pertemuan kelompok tani.

Tingkat kohesi kelompok tani merupakan perasaan anggota kelompok tani sebagai bagian dari kelompok taninya.

c. Sarana dan Prasarana Kelompok Tani Dalam pelaksanaan kegiatan kelompok tani sarana dan prasarana penunjang sangat diperlukan untuk mendukung kegiatan kelompok tani. Adapun sarana dan prasarana yang dimiliki kelompok tani di Kecamatan Sumbergempol adalah :

Tabel 13

Sarana dan Prasarana Kelompok Tani

\begin{tabular}{clcc}
\hline No & Keterangan & Frekuensi & Presentase \\
\hline 1 & Sangat Baik & 25 & 58,14 \\
2 & Baik & 11 & 25,58 \\
3 & Kurang Baik & 7 & 16,28 \\
\hline
\end{tabular}

\begin{tabular}{ccc}
\hline $4 \quad$ Tidak Baik & 0 & 0 \\
Jumlah & 43 & 100 \\
\hline
\end{tabular}

Dari tabel 13 menunjukkan bahwa kelompok tani sebagian besar adalah telah memiliki sarana dan prasarana penunjang kegiatan kelompok dengan kategori sangat baik, yaitu $25(58,14 \%)$ dan kategori kurang baik 7 (16,28\%). Ini menunjukkan bahwa kelompok tani di Kecamatan Sumbergempol Kabupaten Tulungagung sangat aktif sehingga selalu berusaha memajukan kelompoknya dengan selalu mengajukan bantuan sarana dan prasarana kepada pemerintah untuk menunjang produksi pertaniannya.

\section{d. Pengetahuan Kelompok Tani}

Berdasarka hasil analisis data pengetahuan kelompok tani di Kecamatan Sumbergempol dapat dilihat pada tabel berikut ini :

Tabel 14

Pengetahuan Kelompok Tani

\begin{tabular}{clcc}
\hline No & Keterangan & Frekuensi & Presentase \\
\hline 1 & Sangat Baik & 12 & 27,91 \\
2 & Baik & 26 & 60,47 \\
3 & Kurang Baik & 5 & 11,62 \\
4 & Tidak Baik & 0 & 0 \\
Jumlah & 43 & 100 \\
\hline
\end{tabular}

Dari tabel 14 menunjukkan bahwa pengetahuan kelompok tani sebagian besar adalah baik, yaitu $26(60,47 \%)$ dan kurang baik 5 (11,62\%). Ini berarti kemampuan petani di Kecamatan Sumbergempol Kabupaten Tulungagung cukup baik untuk menerima dan menerapkan teknologi baru pertanian.

Pengetahuan kelompok tani sangat mempengaruhi perkembangan kelompok dalam menerima informasi dan beruasaha tani, semakin mereka sadar akan pentingnya pengetahuan tentang caracara bertani yang modern maka akan semakin meningkatkan tingkat produksi dan kesejahteraan petani.

e. Kinerja Kelompok Tani 
Berdasarkan data tingkat usaha kelompok tani, tingkat kohesi kelompok tani, sarana dan prasarana yang dimiliki kelompok tani, dan pengetahuan kelompok tani, maka kinerja kelompok tani di Kecamatan Sumbergempol adalah sebagai berikut :

Tabel 15

Kinerja Kelompok Tani

\begin{tabular}{clcc}
\hline No & Keterangan & Frekuensi & Presentase \\
\hline 1 & Sangat Baik & 30 & 69,77 \\
2 & Baik & 8 & 18,60 \\
3 & Kurang Baik & 5 & 11,63 \\
4 & Tidak Baik & 0 & 0 \\
Jumlah & 43 & 100 \\
\hline
\end{tabular}

Dari Tabel 15 menunjukkan bahwa kinerja kelompok tani di Kecamatan Sumbergempol sebagian besar adalah tinggi, yaitu $30(69,77 \%), \quad 8 \quad(18,60 \%)$ adalah baik dan $5(11,63 \%)$ kurang baik.

Kinerja Kelompok Tani di Kecamatan Sumbergempol Kabupaten Tulungagung tergolong tinggi, hal ini disebabkan motivasi dari petugas untuk menumbuh kembangkan kembali kelompok tani kelompok tani yang tadinya sudah tidak bersemangat mengikuti kegiatan kelompok tani cukup besar. Hal ini dibuktikan dengan kesedian petugas penyuluh untuk selalu hadir dalam undangan pertemuan kelompok tani, menciptakan keakraban dengan kelompok tani serta meningkatkan kembali kepercayaan kelompok tani tentang pentingnya kehadiran petugas penyuh di tengah - tengah kegiatan pertanian mereka.

Sistem penyuluhan yang modern dan transparansi membuat kelompok tani kembali menghargai dan merasa membutuhkan bimbingan, nasehat dan petunjuk dari petuga penyuluh.

\section{Hubungan Peran Penyuluh Pertanian Lapangan (PPL) terhadap Kinerja Kelompok Tani}

Dari hasil analisa data yang dilakukan dengan menggunakan korelasi Rank Spearman didapatkan hasil sebagai berikut :

Tabel 16

Hasil Analisa Korelasi Rank Spearman

\begin{tabular}{|c|c|c|c|c|}
\hline & & & $\begin{array}{c}\text { Peran } \\
\text { Penyulu } \\
\text { h }\end{array}$ & $\begin{array}{l}\text { Kinerja } \\
\text { Kelomp } \\
\text { ok Tani }\end{array}$ \\
\hline \multirow[t]{6}{*}{$\begin{array}{l}\text { Spearm } \\
\text { an's rho }\end{array}$} & $\begin{array}{l}\text { Peran } \\
\text { Penyuluh }\end{array}$ & $\begin{array}{l}\text { Correlatio } \\
\mathrm{n} \\
\text { Coefficient }\end{array}$ & 1.000 & $.799^{\prime \prime}$ \\
\hline & & $\begin{array}{l}\text { Sig. }(2- \\
\text { tailed) }\end{array}$ & & .000 \\
\hline & & $\mathrm{N}$ & 43 & 43 \\
\hline & $\begin{array}{l}\text { Kinerja } \\
\text { Kelompok } \\
\text { Tani }\end{array}$ & $\begin{array}{l}\text { Correlatio } \\
\mathrm{n} \\
\text { Coefficient }\end{array}$ & $.799^{* *}$ & 1.000 \\
\hline & & $\begin{array}{l}\text { Sig. (2- } \\
\text { tailed) }\end{array}$ & .000 & \\
\hline & & $\mathrm{N}$ & 43 & 43 \\
\hline
\end{tabular}

**. Correlation is significant at the 0.01 level (2tailed).

Berdasarkan Tabel 4.18 menunjukkan bahwa hasil uji ststistik dengan spearman's rank correlation didapatkan $\rho$ value 0,000 pada $\alpha=0,05$ dan $r=0,799$ maka $\mathrm{Ho}$ di tolak dan $\mathrm{H}_{1}$ diterima yang artinya ada pengaruh peran penyuluh pertanian lapangan (PPL) terhadap kinerja kelompok tani di Kecamatan Sumbergempol Kabupaten Tulungagung.

\section{Peran Penyuluh Pertanian Lapangan} (PPL)

Kegiatan penyuluhan pertanian sebagai proses belajar bagi petani melalui pendekatan kelompok dan diarahkan untuk terwujudnya kemampuan kerja sama yang lebih efektif sehingga mampu menerapkan inovasi, mengatasi berbagai resiko kegagalan usaha tani, menerapkan skala usaha yang ekonomis untuk memperoleh pendapatan yang layak dan sadar akan peranan serta tanggung jawabnya sebagai pelaku pembangunan, khususnya pembangunan pertanian.

Kehadiran Penyuluh Pertanian Lapangan (PPL) dan peranan penyuluh pertanian di tengah-tengah masyarakat tani di desa masih sangat dibutuhkan untuk meningkatkan sumber daya manusia (petani) sehingga mampu mengelola sumber daya alam yang ada secara intensif demi tercapainya peningkatan produktifitas dan pendapatan atau tercapainya ketahanan pangan dan ketahanan ekonomi. Memberdayakan petani dan keluarganya 
melalui penyelenggaraan penyuluh pertanian, bertujuan untuk mencapai petani yang tangguh sebagai salah satu komponen untuk membangun pertanian yang maju, efisien dan tangguh sehingga terwujudnya masyarakat sejahtera.

Upaya Petugas Penyuluh Lapangan dalam upaya meningkatkan usaha tani di Kecamatan Sumbergempol secara umum sudah dilaksanakan dengan baik, artinya bahwa prosedur pelaksanaan penyuluhan dari mulai dari penyusunan rencana dan jadwal kerja, persiapan administrasi kunjungan lapangan, persiapan bahan alat penyuluhan, pelaksanan programprogram penyuluhan dan mekanisme pelaksanaan penyuluhan pertanian sudah disusun secara sistematis. Tugas pembinaan dilakukan untuk meningkatkan sumberdaya petani di bidang pertanian, di mana untuk menjalankan tugas ini di masa depan penyuluh harus memiliki kualitas sumberdaya yang handal, memiliki kemandirian dalam bekerja, profesional serta berwawasan global.

Peranan agen penyuluhan pertanian adalah membantu petani membentuk pendapat yang sehat dan membuat keputusan yang baik dengan cara komunikasi yang baik dengan cara memberikan informasi yang mereka perlukan. Sekarang peranan penyuluhan lebih dipandang sebagai proses membantu petani untuk mengambil keputusan sendiri dengan cara menolong mereka mengembangkan wawasan mengenai konsekwensi dari masingmasing pilihan itu. Petani mendapatkan informasi informasi tidak hanya dari agen penyuluhan, tetapi juga dari beberapa sumber lain, termasuk pengalaman mereka sendiri serta pengalaman mitra mereka untuk mengembangkan wawasan. Beberapa program penyuluhan yang dilakukan diantaranya SLPTT (Sekolah Lapang Pengelolaan Tanaman Terpadu), SLPHT (Sekolah Lapang Pengendalian Hama Terpadu), P4K (Pembinaan Peningkatan Pendapatan Petani Kecil) dan PUAP (Pengembangan Usaha Agribisnis Pedesaan).
Setiap program pengembangan sektor pertanian khususnya yang berkait dengan program pengembangan SDM pertanian harus merupakan bagian integral dari peningkatan kesejahteraan petani. Keberhasilan petugas penyuluh lapangan ditunjukkan dari Sembilan indicator yang dijadikan parameter keberhasilannya. Hasil penelitian menunjukkan dari Sembilan indikator tersebut terdapat dua indikator yang belum optimal sedangkan tujuh sisanya dinilai oleh petani sudah sesuai dengan harapan.

Proses penyelenggaraan penyuluhan pertanian dapat berjalan dengan baik dan benar apabila didukung dengan tenaga penyuluh yang profesional, kelembagaan penyuluh yang handal, materi penyuluhan yang terus-menerus mengalir, sistem penyelenggaraan penyuluhan yang benar serta metode penyuluhan yang tepat dan manajemen penyuluhan yang polivalen. Dengan demikian penyuluhan pertanian sangat penting artinya dalam memberikan modal bagi petani dan keluargannya, sehingga memiliki kemampuan menolong dirinya sendiri untuk mencapai tujuan dalam memperbaiki kesejahteraan hidup petani dan keluarganya.

\section{Kinerja Kelompok Tani}

Berdasarkan Tabel 15 menunjukkan bahwa kinerja kelompok tani di Kecamatan Sumbergempol sebagian besar adalah sangat baik, yaitu $30(69,77 \%)$. Ini berarti kelompok tani di Kecamatan Sumbergempol telah menunjukkan tingkat usaha tani yang lebih maju.

Pertumbuhan kelompok tani yang sangat pesat di Kecamatan Sumbergempol Kabupaten Tulungagung tidak lepas dari peran Petugas Penyuluh Lapangan (PPL) yang saat ini telah berusaha meningkatkan pendidikannya dengan melanjutkan kejenjang pendidikan yang lebih tinggi. Pendekatan petugas kepada kelompok tani untuk menjalin hubungan saling percaya dengan aktif menghadiri undangan pertemuan kelompok tani ternyata mendapatkan respon yang cukup baik dari anggota kelompok tani sehingga mereka mau aktif 
kembali. Kegiatan pertemuan kelompok tani merupakan wahana bagi petugas penyuluh untuk menyampaikan ilmu dan teknologi pertanian yang modern dan sumber ilmu bagi anggota kelompok tani.

Agar usahatani dapat dilakukan dengan baik dan untuk meningkatkan produksi maka diperlukan beberapa sarana produksi, seperti : ketersediaan bibit, pupuk, estisida, ala-alat pertanian, mesinmesin pertanian, saluran irigasi, tenaga kerja dan lain-lain (Deptan, 2010).

Kesemua sarana dan prasarana tersebut telah banyak dimiliki dan tersedia di kelompok tani Kecamatan Sumbergempol Kabupaten Tulungagung, semua berkat bimbingan dan arahan dari petugas penyuluh pertanian yang senantiasa memberikan informasi dengan cepat terhadap adanya program bantuan dari pemerintah daerah maupun pusat.

\section{Peran Penyuluh Pertanian Lapangan (PPL) Terhadap Kinerja Kelompok Tani} Dari Tabel 16 diketahui bahwa hasil uji ststistik dengan spearman's rank correlation diperoleh $\rho$ value 0,000 pada $\alpha$ $=0,05$ dan $r=0,799$ maka Ho di tolak dan $\mathrm{H}_{1}$ diterima yang artinya ada pengaruh peran penyuluh pertanian lapangan (PPL) terhadap kinerja kelompok tani di Kecamatan Sumbergempol Kabupaten Tulungagung. Dengan demikian terdapat hubungan yang signifkan antara peran penyuluh pertanian dengan kinerja kelompok tani, dimana jika peranan penyuluh pertanian tinggi maka kinerja kelompok tani juga tinggi, begitu pula sebaliknya, apabila peranan penyuluh pertanian rendah maka kinerja kelompok tani juga rendah. Tingkat hubungan antara peran penyuluh pertanian dengan kinerja kelompok tani dikatakan cukup kuat karena diperoleh nilai korelasi sebesar 0,799 .

\section{PENUTUP \\ Simpulan}

Kesimpulan dari penelitian ini adalah: 1) Persepsi kelompok tani terhadap kinerja petugas penyuluh lapangan secara keseluruhan dinilai sudah cukup baik, artinya dari Sembilan indikator kinerja petugas sebanyak tujuh indikator sudah sesuai dengan harapan petani di Kecamatan Sumbergempol Kabupaten Tulungagung sedangkan dua indikator belum sesuai dengan harapan para petani di Kecamatan Sumbergempol Kabupaten Tulungagung yaitu terwujudnya kemitraan usaha antara pelaku utama dengan pelaku usaha yang saling menguntungkan dan terwujudnya akses pelaku utama dan pelaku usaha ke lembaga keuangan, informasi sarana produksi dan pemasaran. 2) Kinerja Kelompok Tani di Kecamatan Sumbergempol Kabupaten Tulungagung adalah kategori sangat baik.

3) Terdapat hubungan yang signifikan antara Peran Penyuluh Pertanian Lapangan (PPL) terhadap Kinerja Kelompok Tani di Kecamatan Sumbergempol Kabupaten Tulungagung dengan nilai $\rho$ value $=0,000<\alpha=0,05$ dan $r=0,799$ dengan tingkat hubungan Kuat.

Saran

Hendaknya petani di Kecamatan Sumbergempol Kabupaten Tulungagung lebih proaktif dalam menjalin kerjasama dengan petugas penyuluh lapangan. Partisipasi dan kontribusi petani terhadap perkembangan agribisnis sangat besar. Petani hendaknya juga ikut berupaya dalam mengatasi masalah-masalah yang selama ini muncul seperti kepemilikan modal yang kecil, penggunaan teknologi yang rendah, pemilikan lahan yang sempit, ancaman iklim seperti banjir dan kekeringan, gangguan hama dan penyakit tanaman, serta akses yang sangat kecil terhadap sumberdana dan informasi. Dan juga Perlu adanya peningkatan peran penyuluh pertanian yang dapat memberikan dampak positif terhadap kinerja kelompok tani. Meningkatkan kinerja kelompok tani khususnya bagi kelompok-kelompok yang masih belum aktif dengan melalui pendekatan personal yang efektif. Bagi petani hendaknya senantiasa belajar dan meningkatkan pengetahuan serta ketrampilannya sehingga menjadi petani yang mandiri dan senantiasa berinovasi untuk meningkatkan pengahasilan yang layak. 
DAFTAR PUSTAKA

BPSDMP Deptan RI. 2009. Modul Diklat Dasar Umum Bagi Penyuluh, Peranan, Tugas dan Fungsi Penyuluh Pertanian. STTP. Bogor.

Arikunto, Suharsimi. 2006. Prosedur Penelitian Suatu Pendekatan Praktek. Jakarta : Rineka Cipta

Departemen Pertanian, 2006. UndangUndang Republik Indonesia Nomor 16 Tahun 2006 Tentang Sistem Penyuluhan Pertanian, Perikanan dan Kehutanan, Jakarta

Hawkins dan Van den Ban. 1999. Penyuluhan Pertanian. Yogyakarta : Kanisius

Hermayunita. 2011. Peran Penyuluh Pertanian Lapangan (PPL) Dalam Penerapan Pertanian Organik di Kenagarian Koto Tinggi Kecamatan Baso Kabupaten Agam. http://repository.unand.ac.id. Diakses tanggal 2 Januari 2015

Kartasapoetra, A. G. 1994. Teknologi Penyuluhan Pertanian. Jakarta : Bumi Aksara.

Nursalam dan Pariani. (2001), Pendekatan Praktis Metode Riset Keperawatan. Jakarta : Sagung Seto.

----- . 2003. Konsep dan Penerapan Metodologi Penelitian IImu Keperawatan. Salemba Medika : jakarta

Permentan RI No. 82/Permentan/OT.140/8/2013.

Tentang Pedoman Pembinaan Kelompoktani dan Gabungan Kelompoktani. Jakarta

Permentan $\mathrm{RI}$ No. 91/Permentan/OT.140/9/2013. Tentang Pedoman Evaluasi Kinerja Penyuluh Pertanian. Jakarta

Pusat Penyuluhan Pertanian Badan Penyuluhan dan Pengembangan SDM Pertanian.2012.Peningkatan kemampuan kelompok tani.

Rasyid, M.A. 2001. Sangat Diperlukan Kegiatan Penyuluh Pertanian. Ekstensia. Vol 13 tahun VII. September 2001

Sinar Tani. 2014. Membangun Kemandirian Agribisnis. Edisi $17-23$ September 2014 No. 3574 Tahun XLV. Jakarta
Sugiyono. 2007. Metode Penelitian Pendidikan dan Pendekatan Kuantitatif, Kualitatif, dan R\&D. Alfabeta, Bandung (ID).

Syofian Siregar, Ir., M.M. (2013). Statistik Parametrik Untuk Penelitian Kuantitatif. Jakarta : Bumi Aksara

Watik Praktiknya, Ahmad, Dr. 2007. Dasar - Dasar Metodologi Keperawatan Konsep dan Praktik. Jakarta : Salemba Medika 